\title{
Corrigendum
}

\section{Objectscapes: a manifesto for investigating the impacts of object flows on past societies_CORRIGENDUM} Martin Pitts \& Miguel John Versluys

Published by Cambridge University Press, 11 February 2021

In the article, Martin Pitts was incorrectly identified as the corresponding author. The correct corresponding author for this article is Miguel John Versluys ( $₫$ m.j.versluys@arch.leidenuniv.nl).

\section{Full reference}

Pitts, M. \& M.J. Versluys. 2021. Objectscapes: a manifesto for investigating the impacts of object flows on past societies. Antiquity 95: 367-81.

https://doi.org/10.15184/aqy.2020.148

(C) The Author(s), 2022. Published by Cambridge University Press on behalf of Antiquity Publications Ltd. This is an Open Access article, distributed under the terms of the Creative Commons Attribution licence (http://creativecommons. org/licenses/by/4.0/), which permits unrestricted re-use, distribution, and reproduction in any medium, provided the original work is properly cited. 